\title{
Pengaruh Sosialisasi DAGUSIBU Obat Tetes Mata Terhadap Peningkatan Pengetahuan Masyarakat Melalui Media Sosial Instagram
}

\author{
${ }^{* 1}$ Hidayah Karuniawati, ${ }^{1}$ Salsabila, ${ }^{1}$ Trisya Nur Pratiwi, ${ }^{1}$ Kurnia Eryani, ${ }^{1}$ Devi Rahmawati, ${ }^{1}$ Rahma Saritri \\ Cahyani, ${ }^{1}$ Amalya Maulida, ${ }^{1}$ Thalia Fiandra, ${ }^{1}$ Zuhroh Tustika Vieda, ${ }^{1}$ Oktri Viyanti \\ ${ }^{1}$ Fakultas Farmasi, Universitas Muhammadiyah Surakarta \\ *Penulis korespondensi, email: hk170@ums.ac.id
}

(Received: 18 January 2021/Accepted: 26 January 2021/Published: 28 January 2021)

\begin{abstract}
Abstrak
Obat tetes mata merupakan salah satu sediaan steril yang berupa larutan atau suspensi. Pengetahuan sebagian masyarakat terkait obat tetes mata masih kurang. Program DAGUSIBU (dapatkan, gunakan, simpan, buang) obat yang diprakarsai oleh Ikatan Apoteker Indonesia (IAI) merupakan salah satu srategi dalam mencapai pengetahuan, pemahaman dan kesadaran masyarakat terhadap penggunaan obat dengan benar. Kegiatan ini bertujuan untuk mengetahui pengaruh penyuluhan terhadap pengetahuan masyarakat tentang cara mendapatkan, menggunakan, menyimpan, dan membuang obat tetes mata dengan benar. Penyuluhan dilakukan melalui media sosial Instagram yang berupa video edukasi animasi yang berdurasi 2 menit 09 detik. Sebelum dan setelah menyaksikan video penyuluhan, responden diminta untuk mengisi kuesioner yang diberikan melaui google form. Data pre-test dan post-test dilakukan uji normalitas dan dilanjutkan dengan uji t berpasangan. Sebanyak 82 responden berpartisipasi dalam sosialisasi tetes mata. Hasil analisis secara deskriptif menunjukkan terjadi peningkatan pengetahuan responden dengan kisaran antara 2,4\% sampai 30,5\%. Uji normalitas didapatkan hasil bahwa jawaban kuesioner terdistribusi normal dengan nilai $p$ value > 0,05. Uji $t$ berpasangan menunjukkan nilai p value < 0,05 yang berarti bahwa penyuluhan secara online melalui media sosial dapat meningkatkan pengetahuan masyarakat tentang obat tetes mata secara signifikan.
\end{abstract}

Kata Kunci: Dagusibu, Obat tetes mata, media sosial, Instagram

\begin{abstract}
Eye drops are a sterile preparation in the form of a solution or suspension. The knowledge of some people regarding eye drops is still lacking. The DAGUSIBU (get, use, store, discard) drug program initiated by the Indonesian Pharmacist Association is a strategy in achieving knowledge, understanding and public awareness of the correct use of drugs. This activity aims to determine the effect of education on public knowledge about how to get, use, store, and dispose of eye drops properly. The counseling was carried out through Instagram social media in the form of an animated educational video that lasted 2 minutes 09 seconds. Before and after watching the counseling video, respondents were asked to fill out a questionnaire given via google form. The pre-test and post-test data were tested for normality and followed by paired t test. A total of 82 respondents participated in the eye drop socialization. The results of the descriptive analysis showed that there was an increase in the respondent's knowledge in the range of $2.4 \%$ to $30.5 \%$. The normality test showed that the answers to the questionnaire were normally distributed with a p value $>0.05$. Paired t test shows a p value <0.05, which means that online counseling through social media can significantly increase public knowledge about eye drops.
\end{abstract}

Keywords: Dagusibu, eye drops, social media, Instagram 


\section{Pendahuluan}

Obat tetes mata merupakan salah satu sediaan steril yang berupa larutan atau suspensi. Pengaplikasian obat nya ditujukan untuk mata, dengan cara meneteskan obat pada selaput lendir mata disekitar kelopak mata dan bola mata. Obat mata digunakan sebagai obat dengan efek lokal. Larutan obat mata adalah larutan steril, bebas partikel asing dan merupakan sediaan yang dikemas sedemikian rupa sehingga sesuai digunakan pada mata (Laila et al, 2019). Efek yang diharapkan dari penggunaan obat tetes mata yaitu untuk pengobatan lokal seperti pengatasan pada mata merah, gatal, dan iritasi. Obat tetes mata yang tersedia di pasaran terdapat dalam 3 golongan, yaitu obat bebas, obat bebas terbatas, dan obat keras.

Pengetahuan sebagian masyarakat tentang penggunaan obat tetes mata dengan benar masih kurang. Pengetahuan yang minim kemungkinan disebabkan oleh kurangnya informasi yang diperoleh masyarakat akan penggunaan obat terutama obat tetes mata dengan benar. Pengetahuan masyarakat dalam menggunakan obat-obatan sangat penting terhadap keberhasilan terapi dan dapat mengurangi terjadinya medication error. Pengobatan sendiri atau swamedikasi merupakan salah satu cara seseorang untuk melakukan pemilihan dan penggunaan obat yang berujuan untuk mengurangi atau melindungi diri dari penyakit atau gejala. Lebih dari 50\% masyarakat melakukan swamedikasi atas inisiatif sendiri (Anggaranti dan Karuniawati, 2018). Swamedikasi dilakukan paling banyak oleh wanita dan sekitar 25\% melakukan swamedikasi karena menganggap penyakit yang dideritanya adalah penyakit ringan dan mudah dikenali (Damayanti dan Karuniawati, 2017; Sasmita dan Karuniawati, 2018). Dalam kasus penggunaan obat mata, ketika mata terasa gatal atau perih, tidak sedikit orang langsung menggunakan obat tetes mata yang dapat dibeli di apotek atau toko terdekat tanpa petunjuk dari dokter. Sementara itu, terlalu sering menggunakan obat tetes mata dapat menimbulkan bahaya (Julianto et al, 2015). Pemilihan obat harus tepat dan benar cara penggunaannya seperti aturan pemakaian, cara pemberian, pengaturan dosis yang sesuai dengan pemakaiannya, dan waspada terhadap kemungkinan efek samping yang tidak diinginkan.

Beberapa studi menyebutkan hanya terdapat 5\% subjek yang menggunakan obat tetes mata dengan benar (Eaton et al, 2015). Sedangkan dalam studi lainnya pasien yang belum pernah menggunakan obat tetes mata menunjukkan bahwa $31 \%$ pasien dapat menggunakan satu atau dua tetes mata dengan benar, dan $31 \%$ pasien yang lain gagal untuk meneteskan ke mata mereka dengan benar, dan 57\% pasien menggunakan obat tetes mata dengan menyentuh mata atau ocular adnexa dengan ujung botol (Lawson et al, 2014). Salah satu program DAGUSIBU (dapatkan, gunakan, simpan, buang) obat yang diprakarsai oleh Ikatan Apoteker Indonesia (IAI) merupakan salah satu strategi dalam mencapai pemahaman dan kesadaran masyarakat terhadap penggunaan obat dengan benar (PP IAI, 2014). Perlu dilakukan sosialisasi penggunaan obat tetes mata yang benar sehingga diharapkan terjadi peningkatan pengetahuan dan pemahaman masyarakat yang berdampak pada cara mendapatkan, menggunakan, menyimpan, dan membuang obat tetes mata dengan benar dan terapi dapat tercapai secara optimal.

\section{Metode}

Program ini dilakukan dengan menggunakan metode quasi-experimental dengan memberikan perlakuan berupa video kepada responden. Responden mengisi kuesioner sebanyak dua kali yaitu sebelum dan setelah menyaksikan video sosialisasi. Batasan operasional program ini meliputi pengetahuan mengenai cara mendapatkan obat tetes mata, cara menggunakan obat tetes mata dengan benar, cara penyimpanan obat tetes mata dan cara pembuangan obat mata yang benar.

Alat yang digunakan adalah kuesioner dalam bentuk google form. Kuesioner berisi aspek pengetahuan yang terdiri dari 10 pernyataan. Bentuk pernyataan yang ada di dalam kuesioner menggunakan variasi (dichotomous choice) dengan dua pilihan jawaban yaitu benar atau salah. Metode yang digunakan yakni metode penyuluhan. Materi penyuluhan disampaikan dalam bentuk video edukasi berupa video animasi yang berdurasi 2 menit 09 detik mengenai bagaimana cara mendapatkan, cara menggunakan, penyimpanan, dan bagaimana cara pembuangan obat tetes mata yang benar, kemudian dibagikan kepada masyarakat melalui media sosial Instagram. 
Pengolahan jawaban kuesioner dilakukan dengan menghitung persentase secara keseluruhan. Data diuji normalitas dan uji t berpasangan. Nilai $p$ value $<0,05)$ dianggap signifikan.

\section{Hasil dan Pembahasan \\ a. Data demografi responden}

Selama program berlangsung, sebanyak 82 responden berpartisipasi. Usia responden antara 15-24 tahun. Total responden wanita sebesar 77\% dan responden pria 23\%. Hal ini kemungkinan disebabkan karena beberapa hal, diantaranya adalah karena perempuan lebih peduli terhadap kesehatan dan memiliki waktu luang yang lebih banyak dibandingkan dengan laki-laki (Ilmahmudah, 2019). Pendidikan berpengaruh pada pola pikir seseorang untuk menghadapi masalah, dalam hal ini masalah kesehatan. Sebagian besar responden berpendidikan Sekolah Menengah Atas (SMA) yaitu 62\%, Sarjana sebanyak 17\%, Diploma sebanyak $11 \%$, SMK $9 \%$ dan SMP $1 \%$. Salah satu tampilan video penyuluhan dalam Instagram dapat dilihat pada Gambar 1. Data demografi responden dapat dilihat pada Gambar 2 dan 3.

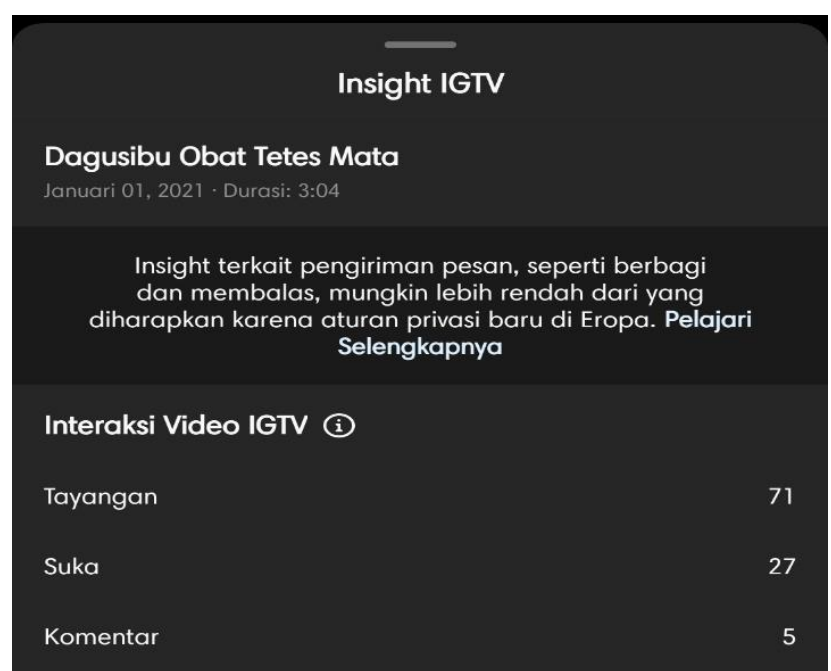

Gambar 1. Salah satu tampilan materi penyuluhan dalam Instagram

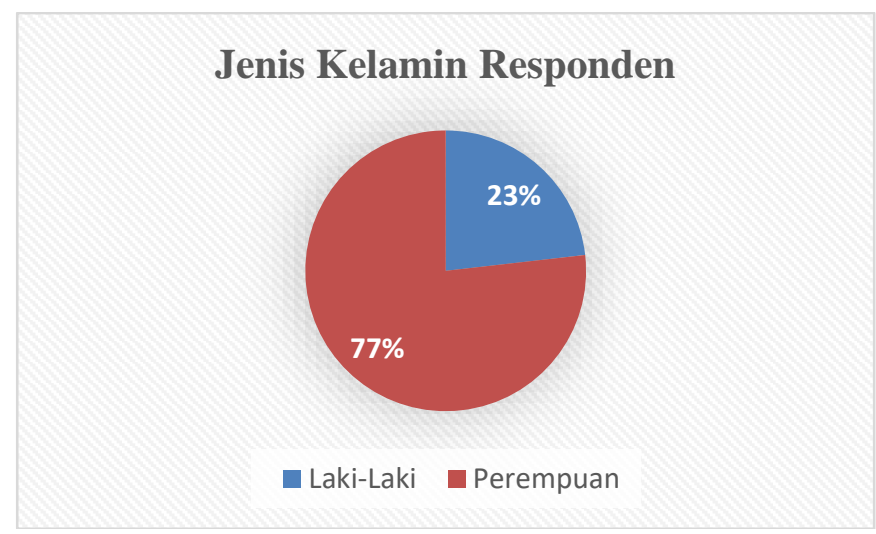

Gambar 2. Jumlah responden berdasarkan jenis kelamin 


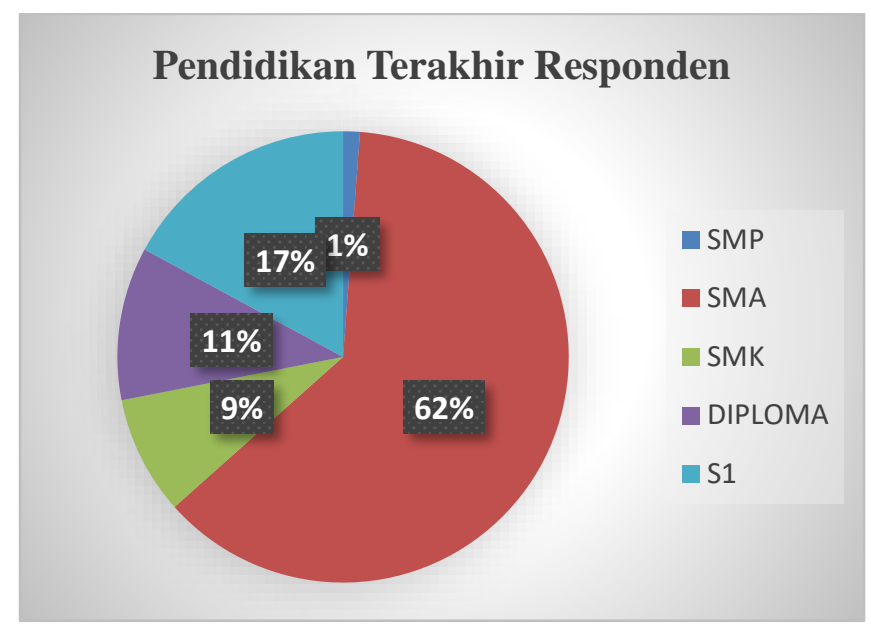

Gambar 3. Jumlah responden berdasarkan pendidikan terakhir

\section{b. Pengetahuan responden terhadap obat tetes mata}

Hasil jawaban yang benar pada kuesioner untuk pre-test dan post-test dapat dilihat pada Tabel 1.

Tabel 1. Persentase hasil jawaban yang benar pada kuesioner Pre-test dan post-test

\begin{tabular}{|c|c|c|c|c|}
\hline No. & Pertanyaan & $\begin{array}{l}\text { Pretest } \\
(\%)\end{array}$ & $\begin{array}{l}\text { Posttest } \\
(\%)\end{array}$ & $\begin{array}{c}\% \\
\text { peningkatan }\end{array}$ \\
\hline 1. & $\begin{array}{l}\text { Tanda lingkaran berwarna merah menunjukkan } \\
\text { kategori obat bebas }\end{array}$ & 73,2 & 84,1 & 10,9 \\
\hline 2. & Obat keras dapat diperoleh tanpa resep dokter & 92,7 & 95,1 & 2,4 \\
\hline 3. & $\begin{array}{l}\text { Obat tetes mata dapat diperoleh dari puskesmas, } \\
\text { rumah sakit, maupun apotek. }\end{array}$ & 100 & 100 & 0 \\
\hline 4. & $\begin{array}{l}\text { Kebersihan tangan adalah hal yang penting dalam } \\
\text { penggunaan obat tetes mata. }\end{array}$ & 97,6 & 100 & 2,4 \\
\hline 5. & $\begin{array}{l}\text { Saat menggunakan obat tetes mata, menyentuh } \\
\text { ujung botol obat tetes mata sebaiknya dihindari. }\end{array}$ & 97,6 & 100 & 2,4 \\
\hline 6. & $\begin{array}{l}\text { Cara meneteskan obat tetes mata yaitu pada } \\
\text { kelopak mata bagian atas. }\end{array}$ & 63,4 & 76,8 & 13,4 \\
\hline 7. & $\begin{array}{l}\text { Setelah meneteskan obat tetes mata harus } \\
\text { didiamkan } 10 \text { menit. }\end{array}$ & 41,5 & 71,95 & 30,5 \\
\hline 8. & $\begin{array}{l}\text { Obat tetes mata dapat disimpan di kulkas maupun } \\
\text { ruangan terbuka }\end{array}$ & 51,2 & 65,85 & 14,7 \\
\hline 9. & $\begin{array}{l}\text { Obat tetes mata dapat digunakan sampai } 4 \text { pekan } \\
\text { setelah kemasan dibuka. }\end{array}$ & 70,7 & 84,1 & 13,4 \\
\hline 10. & $\begin{array}{l}\text { Pembuangan obat tetes mata yaitu dengan cara } \\
\text { merobek bagian label dan membuang bagian tutup } \\
\text { dan botolnya secara terpisah. }\end{array}$ & 68,6 & 95,1 & 26,5 \\
\hline
\end{tabular}


Tabel 1 menunjukkan bahwa secara umum terjadi peningkatan pengetahuan responden sebelum dan setelah penyuluhan dengan video yang di share melalui Instagram. Jawaban pernyataan nomor 3, 4, 5, 9, 10 adalah benar. Sehingga responden yang menjawab "benar" pada nomor tersebut maka masing-masing jawaban mendapatkan skor 1 dan sebalikanya. Sedangkan jawaban pernyataan nomor 1, 2, 6, 7, 8 adalah salah, sehingga responden yang menjawab "salah" pada nomor tersebut maka mendapatkan skor 1 dan sebaliknya. Peningkatan pengetahuan responden terbesar pada pernyataan no. 7 dan no. 10 sebesar 30,5\% dan $26.5 \%$.

Pada pernyataan no.1, terkait penandaan obat bebas, sebanyak $73,2 \%$ jawaban responden benar. Tanda lingkaran berwarna merah tidak menunjukkan kategori obat bebas tetapi obat keras. Setelah melihat video edukasi, persentase responden yang menjawab pernyataan dengan benar meningkat menjadi $84,1 \%$.

Pada pernyataan no.2, Obat keras dapat diperoleh tanpa resep dokter. Sebanyak 7,3\% responden belum mengetahui bahwa obat keras diperoleh dengan resep dokter. Setelah melihat video edukasi yang diberikan pengetahuan responden meningkat dari 92,7 \% menjadi $95,1 \%$, yang artinya lebih banyak responden yang mengerti bahwa obat keras harus didapatkan dengan resep dokter. Obat Keras adalah obat yang hanya dapat diperoleh dengan resep dokter. Ciricirinya adalah bertanda lingkaran bulat merah dengan garis tepi berwarna hitam, dengan huruf $\mathrm{K}$ ditengah yang menyentuh garis tepi. Obat ini hanya boleh dijual di apotek dan harus dengan resep dokter pada saat membelinya.

Pada pernyataan no.3, obat tetes mata dapat diperoleh dari puskesmas, rumah sakit, maupun apotek. Berdasarkan pada hasil kuesioner pretest, $100 \%$ responden menjawab dengan benar sebelum dan setelah melihat tayangan video edukasi. Hal ini menunjukan bahwa responden telah mengetahui bahwa obat tetes mata dapat diperoleh dari puskesmas, rumah sakit, maupun apotek. Mendapatkan obat tetes mata yang benar dilakukan dengan memperhatikan penggolongan obat, informasi pada kemasan, dan kadaluarsa obat. Masyarakat diharapkan memperoleh obat tetes mata dari sarana kesehatan yang memiliki lisensi atau legal hal ini sesuai dengan peraturan menteri kesehatan republik indonesia no 73 tahun 2016, yang menjelaskan bagaimana cara mendapatkan obat dengan benar (Yasir, et al 2019).

Pada pernyataan no 4 , kebersihan tangan adalah hal yang penting dalam penggunaan tetes mata. Berdasarkan hasil kuesioner pretest terdapat 97,6\% responden menjawab benar dan setelah melihat tayangan video edukasi, $100 \%$ responden menjawab benar pada kuesioner post test. Hal tersebut menunjukkan bahwa setelah melihat video semua responden mengetahui obat tetes mata merupakan sediaan steril sehingga kebersihan tangan adalah hal yang penting dalam penggunaan obat tetes mata.

Pada pernyataan no. 5, saat menggunakan obat tetes mata, menyentuh ujung botol obat tetes mata sebaiknya dihindari. Sebanyak $97,6 \%$ responden menjawab benar dan responden menjawab salah sebanyak $2,4 \%$ dan setelah menonton video responden yang menjawab benar sebanyak $100 \%$. Hal ini menunjukkan pengetahuan responden terhadap cara penggunaan obat tetes mata yang benar sudah sangat baik dan dari hasil tersebut dapat diketahui adanya peningkatan pengetahuan responden setelah menonton video edukasi dengan meningkatnya jawaban benar menjadi $100 \%$. Jika bagian ujung alat penetes menyentuh bagian mata maka bagian ujungnya kemungkinan akan terkontaminasi kuman, sehingga saat obat tetes mata digunakan lagi kuman mudah masuk ke permukaan mata dan menyebabkan terjadinya infeksi (Hyas, 2004).

Pada pernyataan no 6, cara meneteskan obat tetes mata yaitu pada kelopak mata bagian atas. Sebanyak $36,6 \%$ responden memilih jawaban benar dan $63,4 \%$ responden memilih jawaban salah. Setelah melihat video, jawaban yang benar dari responden meningkat dari $63,3 \%$ menjadi $76,8 \%$. Penetesan obat tetes mata yang tepat adalah pada kelopak mata bagian bawah karena kelopak mata bagian bawah lebih membentuk kantung mata daripada kelopak mata bagian atas, sehingga ketika obat diteteskan ke mata maka obatnya akan lebih mudah masuk, dan jika obat tetes mata tersebut banyak terbuang oleh air mata maka masih ada sedikit obat yang tertinggal pada kelopak mata bagian bawah. 
Pada pernyataan no 7, yaitu setelah meneteskan obat tetes mata harus didiamkan selama 10 menit. Sebanyak 58,5\% responden menganggap benar hal tersebut, setelah menonton tayangan video edukasi sebanyak $65,85 \%$ responden menjawab pernyataan tersebut salah, berdasarkan hasil tersebut dapat diketahui bahwa pengetahuan responden meningkat. Setelah meneteskan obat tetes mata, mata ditutup pelan-pelan dan membiarkan mata tertutup selama 1-2 menit (Ikatan Sarjana Farmasi Indonesia, 2009). Pendiaman tersebut bertujuan supaya obat tetes mata yang diteteskan mudah menyebar keseluruh bagian mata dan menambah efektivitas obat.

Secara umum penyimpanan obat tetes mata pada suhu ruang atau kamar. Berdasarkan farmakmakope IV suhu kamar berkisar antara $15^{\circ} \mathrm{C}-30^{\circ} \mathrm{C}$, dikarenakan sediaan obat didalam kemasan sekunder atau primer dalam penyimpanannya akan dipengaruhi oleh faktor lingkungan seperti suhu, cahaya, dan udara. Pengaruh faktor lingkungan lambat laun akan membuat obat terurai secara kimiawi yang mengakibatkan kadar obat dalam sediaan berkurang. Oleh karena itu pada penyimpanan obat harus memperhatikan suhu, udara, dan paparan cahaya. Pengetahuan responden pada pertanyaan no. 8 mengenai obat tetes mata dapat disimpan di kulkas ataupun ruang terbuka. Dapat dilihat adanya peningkatan pemahaman responden untuk menyimpan obat tetes mata di dalam kotak obat atau suhu kamar dengan peningkatan persentase hasil dari 51,2\% menjadi $65,85 \%$ setelah melihat video edukasi.

Obat tetes mata yang disimpan lebih dari 1 bulan setelah kemasan dibuka sterilitasnya sudah tidak terjamin, karena bahan aktif bisa rusak atau sediaan yang seharusnya steril akan terkontaminasi oleh mikroba apabila tetap digunakan dan dikhawatirkan dapat menyebabkan gangguan tambahan pada mata. Pada pernyataan no. 9 obat tetes mata dapat digunakan sampai 4 pekan setelah kemasan dibuka. Sebanyak 70,7\% responden mengetahui bahwa obat mata boleh digunakan tidak lebih dari 4 pekan, dan pada saat responden melihat video edukasi yang diberikan pengetahuan responden meningkat menjadi $84,1 \%$.

Obat yang sudah kadaluarsa atau rusak harus segera dibuang. Cara pembuangan obat tidak boleh sembarangan karena dikhawatirkan akan disalahgunakan oleh orang lain. Cara pembuangannya yang benar adalah dengan melepaskan etiket atau label obat terlebih dahulu kemudian membuang bagian tutup botolnya secara terpisah ke tempat sampah (Lutfiyati, 2017). Sebanyak $86,6 \%$ responden memilih jawaban benar dan menunjukkan persentase yang meningkat menjadi $95,1 \%$ setelah menonton video animasi DAGUSIBU obat tetes.

Analisis jawaban kuesioner dengan melakukan uji normalitas didapatkan hasil bahwa jawaban kuesioner terdistribusi normal dengan nilai $p$ value $>0,05$. Uji $\mathrm{t}$ berpasangan menunjukkan nilai $p$ value $<0,05$, maka disimpulkan bahwa penyuluhan secara online melalui media sosial dapat meningkatkan pengetahuan responden terhadap obat tetes mata secara signifikan.

\section{Simpulan}

Sosialisasi mengenai dagusibu obat tetes mata secara online melalui media sosial (instagram) dapat meningkatkan pengetahuan responden secara signifikan.

\section{Persantunan}

Penulis mengucapkan terimakasih kepada fakultas Farmasi Universitas Muhammadiyah Surakarta, Lembaga Penelitian dan Pengabdian kepada Masyarakat (LPPM UMS) serta semua responden yang sudah berpartisispasi dalam kegiatan sosialisasi ini.

\section{Referensi}

Anggaranti, I. Karuniawati, H. (2018). Profil Pelayanan Swamedikasi Oleh Apoteker Di 6 Apotek Kota Surakarta. Skripsi. Universitas Muhammadiyah Surakarta.

Damayanti, A.D. Karuniawati, H. (2017). Hubungan Tingkat Pengetahuan dengan Ketepatan Penggunaan Obat Analgetik pada Swamedikasi Nyeri Gigi di Masyarakat Kabupaten Sukoharjo. Skripsi. Universitas Muhammadiyah Surakarta. 
Eaton, A. M. Gordon, G.M. Konowal, A. et al. (2015). "A novel eye drop application monitor to assess patient compliance with a prescribed regimen: a pilot study," Eye, vol. 29, no. 10, pp. 1383-1391.

Lawson, M. K. Han, J. T. Sellers et al. (2014). "Aerobic exercise protects retinal function and structure from light-induced retinal degeneration," Journal of Neuroscience, vol. 34, no. 7, pp. 2406-2412.

Hyas, S,H. (2004). Ilmu Perawatan Mata. Sagung seto. Jakarta. pp. 16-21, 201-204.

Ikatan Sarjana Farmasi Indonesia. (2009). Informasi Spesialite Obat Indonesia, Volume 44-2009 s/d 2010. Berlico Mulia Farma. Yogyakarta. pp. 367-381.

Ilmahmudah, L. (2019). Analisis Tingkat Pengetahuan Tentang DAGUSIBU pada Mahasiswa Universitas Ahmad Dahlan Yogyakarta.

Julianto T. Mayasari. Widianti, C. Abadi, F.S. Poniwati, K. Fitri, N.A, et al. (2015). Penggunaan Dan Penyimpanan Sediaan Topikal Multidose Untuk Mata. Jurnal Farmasi Komunitas. Vol. 2, No. 2, 52-56.

Laila, A. N. Fiona L. Yulina. Andi M. R. Nurussalam. Nandiwardana, A. Erlitasar, A.S.et al. (2019). Jurnal Farmasi Komunitas. Vol. 6, No. 1, 9-13.

Lutfiyati, H. Yuliatuti, F. Dianita, P. S. (2017). Pemberdayaan Kader PKK dalam Penerapan DAGUSIBU (Dapatkan, Gunakan, Simpan, dan Buang) Obat dengan Baik dan Benar, The 6th University Research Colloquium, Universitas Muhammadiyah Magelang.

Yasir S. A., Rositasari, E. Pasa, C. (2019). Penyuluhan Tentang DAGUSIBU "Obat Tetes Mata" di Posyandu Lansia Puskesmas Gadingrejo Pringsewu. Jurnal Pengabdian Farmasi Malahayati. 2(1).

PP IAI Pengurus Pusat Ikatan Apoteker Indonesia. (2014). Pedoman Pelaksanaan Keluarga Sadar Obat. Jakarta.

Sasmita, M. Karuniawati, H. (2018). Profil Swamedikasi Pada Mahasiswa Universitas Muhammadiyah Surakarta Periode November-Desember 2017, Skripsi, Universitas Muhammadiyah Surakarta.

(C) 2021 by the authors. Submitted for possible open access publication under the terms and conditions of the Creative Commons Attribution (CC-BY-NC-ND) license (http://creativecommons.org/licenses/by/4.0/). 